\title{
Simulacija ogroženosti površja zaradi snežnih plazov v slovenskih Alpah
}

\author{
Miha Pavšek \\ Mag., Geografski inštitut Antona Melika, Znanstvenoraziskovalni center SAZU, \\ Gosposka ulica 13, 1000 Ljubljana, Slovenija \\ e-mail: miha.pavsek@zrc-sazu.si
}

\section{Izvleček}

Po oblikah površja razgibano in pokrajinsko raznovrstno Slovenijo ogrožajo številne naravne nesreče med katerimi so tudi snežni plazovi. Na temelju dosedanjih ugotovitev in s pomočjo podatkov iz geografskega informacijskega sistema za Slovenijo smo opredelili potencialno plazovito površje na območju slovenskih Alp. Pri tem smo upoštevali rezultate obdelave snežnih plazov iz lavinskega katastra $v$ Julijskih Alpah, ugotovitve drugih podobnih študij ter podatkovne sloje naravnogeografskih sestavin visokogorskih pokrajin.

Ključne besede: fizična geografija, snežni plazovi, naravne nesreče, lavinsko ogrožena območja, potencialna ogroženost, lavinska preventiva

\section{Simulation of Avalanche Threat in the Slovene Alps}

\begin{abstract}
According to its relief, Slovenia is highly variegated and its landscape diverse, and for this reason it is threatened by numerous natural accidents, among which are avalanches. On the basis of previous findings and with the help of data from Slovenia's Geographical Information System, we undertook to determine potential avalanche surfaces in the Slovene Alps. In so doing, we considered the results of data processing on avalanches in the Julian Alps from the avalanche cadastre, other similar studies, and data layers on natural and geographical elements in high-mountain regions. In conclusion, we compared simulated and actual potential avalanche threat areas to assess the validity of our model.
\end{abstract}

Key words: physical geography, avalanches, natural disasters, avalanche endangered areas, potential risk, avalanche accident prevention 


\section{TEMELJNA IZHODIŠČA}

S terenskim deloma lahko v veliki meri opredelimo dejansko lavinsko ogroženost površja pod gozdno mejo, nad njo in na negozdnatem ali celo neporaščenem površju pa je to mnogo težje. $Z$ vse bolj natančnimi naravnogeografskimi podatki na prostorsko enoto lahko izvedemo tudi simulacijo ogroženega površja, pri čemer gre prav tako za potencialno, do sedaj nedokazano ogroženost. Razlikovati moramo pojma dejanska in simulirana lavinska ogroženost. S primerjavo obeh lahko izluščimo nekatere dodatne značilnosti prostorske razporeditve snežnih plazov. Zavedati se moramo, da so na tak način opredeljene površine tiste, ki jih v jih v naravi označujemo kot zbirno območje ali zaledje plazu oziroma območje proženja. Pri predstavljeni simulaciji lavinske ogroženosti ustrezajo te površine v glavnem območju proženja. Do neke mere je moč opredeliti tudi površine, kjer se plazovi iztekajo in torej ustrezajo območju odlaganja. Te so v veliki meri odvisne od prvih, saj so v njihovi vpadnici ali pa na bokih območij proženja posameznih plazov.

V svoji raziskavi sem obdelal območje slovenskih Alp, pri čemer sem upošteval rezultate obdelave snežnih plazov iz lavinskega katastra na območju Julijskih Alp ( $=506)$ ter podatkovne sloje o naravnogeografskih značilnostih štirih pokrajin, ki so pri tipizaciji v Geografskem atlasu Slovenije (Perko 1998b, str. 121) uvrščene $\mathrm{k}$ alpskim visokogorjem.

Pri pripravi tematskega zemljevida sem si pomagal $\mathrm{z}$ nekaterimi ugotovitvami in metodami, ki sta jih uporabila pri določanju lavinsko ogroženega površja na testnem območju Davosa (Švica) Kienholz in Grunder (1986). Model sta zgradila tako, da je uporaben tudi na enakem ali podobnem, to je goratem območju. Dobljeno simulacijo sta nato primerjala $\mathrm{z}$ dejansko lavinsko ogroženostjo površja s pomočjo podatkov iz švicarskega lavinskega katastra. V končnem simulacijskem modelu lavinske ogroženosti površja sta upoštevala predvsem snežne razmere, naklonske in rastne značilnosti površja, rabo tal ter domnevni iztek plazu. Slednjega sta opredelila kot nižje in v vpadnici območja proženja ležeče celice določene dolžine in naklona. Zaradi bistveno večje površine slovenskih Alp od testnega območja v Davosu in s tem natančnosti izvornih podatkov sem se zavedal dejstva, da so tako dobljene površine s simulirano ogroženostjo manj natančne. Vendar pa je glede na stopnjo simulirane ogroženosti še vedno velika verjetnost, da se na teh površinah tudi dejansko lahko prožijo snežni plazovi.

V preglednici 1 so v stolpcih po pomembnosti (stolpci 1 do 7) predstavljeni posamezni dejavniki oziroma sestavine ogroženosti po posameznih stopnjah. Na temelju teh sem na koncu opredelil skupno lavinsko ogroženost posameznih hektarskih celic. Vsakega od dejavnikov sem glede na stopnjo la- 
vinske ogroženosti razvrstil $\mathrm{v}$ tri glavne razrede ter opredelil meje med njimi. Mejne vrednosti sem določil s pomočjo podatkov iz različnih virov in literature, katastra ter GIS-a za Slovenijo (GIAM). Pri končni simulaciji pa sem upošteval vseh sedem dejavnikov. Na prvi stopnji simulacije posameznih dejavnikov nisem ponderiral, kasneje pa sem se odločil za ponderiranje naklona, saj je ta med vsemi najpomembnejši. V preglednicah pa predstavljam še delež lavinsko ogroženega površja po stopnjah ogroženosti tako na območju slovenskih Alp kot tudi v okviru vseh ogroženih površin.

Preglednica 1: Izbrani kriteriji za določanje potencialne lavinske ogroženosti površja na območju slovenskih Alp.

\begin{tabular}{|c|c|c|c|c|c|c|c|}
\hline $\begin{array}{l}\text { Stopnja } \\
\text { ogrože- } \\
\text { nosti } \\
\text { (števil- } \\
\text { čno in } \\
\text { opisno) }\end{array}$ & $\begin{array}{c}1 \\
\\
\text { naklon } \\
\text { (v sto- } \\
\text { pinjah) }\end{array}$ & $\begin{array}{c}2 \\
\\
\text { rastje } \\
\text { po višini } \\
\text { (opisno) }\end{array}$ & $\begin{array}{c}3 \\
\text { ekspo- } \\
\text { zicija } \\
\text { (strani } \\
\text { neba) }\end{array}$ & $\begin{array}{l}4 \\
\text { trajanje } \\
\text { snežne } \\
\text { odeje } \\
\text { (št. dni } \\
\text { na leto) }\end{array}$ & $\begin{array}{c}5 \\
\text { maks. } \\
\text { višina } \\
\text { snežne } \\
\text { odeje } \\
\text { (m) }\end{array}$ & $\begin{array}{l}\text { nadm. } \\
\text { višina } \\
\text { (m) }\end{array}$ & $\begin{array}{c}7 \\
\text { tipi } \\
\text { podnebja } \\
\text { (opisno) }\end{array}$ \\
\hline $\begin{array}{c}3 \\
\text { velika }\end{array}$ & 31 do 45 & $\begin{array}{l}\text { rastje skalnih } \\
\text { razpok, alpskih } \\
\text { melišč in prodišč, } \\
\text { subalpinskih } \\
\text { in alpinskih travišč, } \\
\text { kmet. zemljišča }\end{array}$ & $\mathrm{J}, \mathrm{JV}, \mathrm{JZ}$ & nad 150 & $\operatorname{nad} 3,0$ & $\begin{array}{c}\text { nad } \\
1600\end{array}$ & $\begin{array}{l}\text { podnebje } \\
\text { višjega } \\
\text { gorskega } \\
\text { sveta }\end{array}$ \\
\hline $\begin{array}{c}2 \\
\text { zmerna }\end{array}$ & $\begin{array}{l}21 \text { do } 30 \\
46 \text { do } 60\end{array}$ & $\begin{array}{l}\text { subalpsko grmišče } \\
\text { ruševja }\end{array}$ & $\mathrm{Z}, \mathrm{SZ}$ & $\begin{array}{c}75 \text { do } \\
150\end{array}$ & $\begin{array}{c}1,0 \text { do } \\
3,0\end{array}$ & $\begin{array}{c}1200 \\
\text { do pod } \\
1600\end{array}$ & $\begin{array}{l}\text { podnebje } \\
\text { nižjega } \\
\text { gorskega } \\
\text { sveta } \\
\text { zahodne } \\
\text { Slovenije }\end{array}$ \\
\hline $\begin{array}{c}1 \\
\text { majhna }\end{array}$ & $\begin{array}{c}11 \text { do } 20 \\
61 \text { in } \\
\text { več }\end{array}$ & $\begin{array}{c}\text { nizki gozd } \\
\text { ali grmišče gabrovca } \\
\text { in hrastov, } \\
\text { omelike ali malega } \\
\text { jesena }\end{array}$ & $\mathrm{V}, \mathrm{S}, \mathrm{SV}$ & pod 75 & pod 1,0 & $\begin{array}{c}300 \\
\text { do pod } \\
1200\end{array}$ & $\begin{array}{c}\text { podnebje } \\
\text { nižjega } \\
\text { gorskega } \\
\text { sveta } \\
\text { severne } \\
\text { Slovenije } \\
\text { in drugi } \\
\text { podnebni } \\
\text { tipi }\end{array}$ \\
\hline $\begin{array}{c}0 \\
\text { neogro- } \\
\text { ženo }\end{array}$ & $\begin{array}{l}10 \text { in } \\
\text { manj }\end{array}$ & drugo rastje & - & - & - & $\begin{array}{l}\text { pod } \\
300\end{array}$ & - \\
\hline
\end{tabular}




\section{NAKLON}

Temeljni vir za določanje naklonskih značilnosti slovenskih Alp glede lavinske ogroženosti je bil zemljevid naklonov površja iz GIS-a za Slovenijo (GIAM). Pri določanju mejnih vrednosti za posamezne razrede ogroženosti (preglednica 1, stolpec 1) sem si pomagal z rezultati obdelave podatkov iz lavinskega katastra kot tudi z literaturo. Naklon od 31 do $45^{\circ}$ ima v Julijskih Alpah na območju proženja več kot tri četrtine plazov, vrednosti iz drugega razreda pa nekaj manj kot četrtina. Naklonske značilnosti plaznic pri preučevanju snežnih plazov za daljše časovno obdobje so tako stalne, da jih lahko upoštevamo kot konstanto. Zato predstavljam naklonske značilnosti nekoliko podrobneje.

Pri naklonu je za proženje snežnih plazov ugodna večina površja slovenskih Alp (slika 1). Analiza lavinske ogroženosti po naklonih (preglednica 2) nam kaže, da je takega površja kar $86,4 \%$. Skoraj tri desetine površja v slovenskih Alpah je tako strmih, da je na njih velika lavinska ogroženost, na tretjini pa zmerna. Kot lavinsko neogrožena območja izstopajo dna dolin in kotlin, nekatere pobočne police in planotasti sredogorski, predgorski ter visokogorski svet. Povsem drugačna pa je slika na njihovem robu.

V Julijskih in Kamniško-Savinjskih Alpah je zmerno ogroženo površje pogosto $\mathrm{v}$ obliki otokov znotraj površin $\mathrm{z}$ veliko ogroženostjo. To pomeni, da se naklon pobočij nižje spodaj spet poveča. S tem je izpolnjen eden od predpogojev za nadaljevanje poti snežnih gmot proti dolini. Ta značilnost je predvsem posledica podobne geotektonske zgradbe obeh visokogorskih pokrajin, saj prekinjajo pobočja številni kamninski pasovi in geološke strukture. Karavanke po lavinski ogroženosti glede naklonov prav nič ne zaostajajo za drugima dvema visokogorskima pokrajinama, $\mathrm{v}$ drobnem celo prav nasprotno. Nekatera pobočja so še daljša in bolj zglajena, saj jih ne prekinjajo vmesni skoki in pregibi.

Preglednica 2: Simulacija lavinske ogroženosti v slovenskih Alpah - naklon.

\begin{tabular}{|l|c|}
\hline Stopnja ogroženosti & Delež površja (v \%) \\
\hline Velika (3) & 28,9 \\
\hline Zmerna (2) & 33,7 \\
\hline Majhna (1) & 23,8 \\
\hline Neogroženo (0) & 13,6 \\
\hline skupaj: & 100,0 \\
\hline
\end{tabular}

V vseh treh pokrajinah je dejanska lavinska ogroženost glede naklonov površinsko mnogo manjša, saj moramo izločiti večino pobočij, ki so pod gozdom. Nekaj kmetijskih zemljišč kot tudi poselitev se krajevno še vedno drži 
Simulacija ogroženosti površja zaradi snežnih plazov v slovenskih Alpah

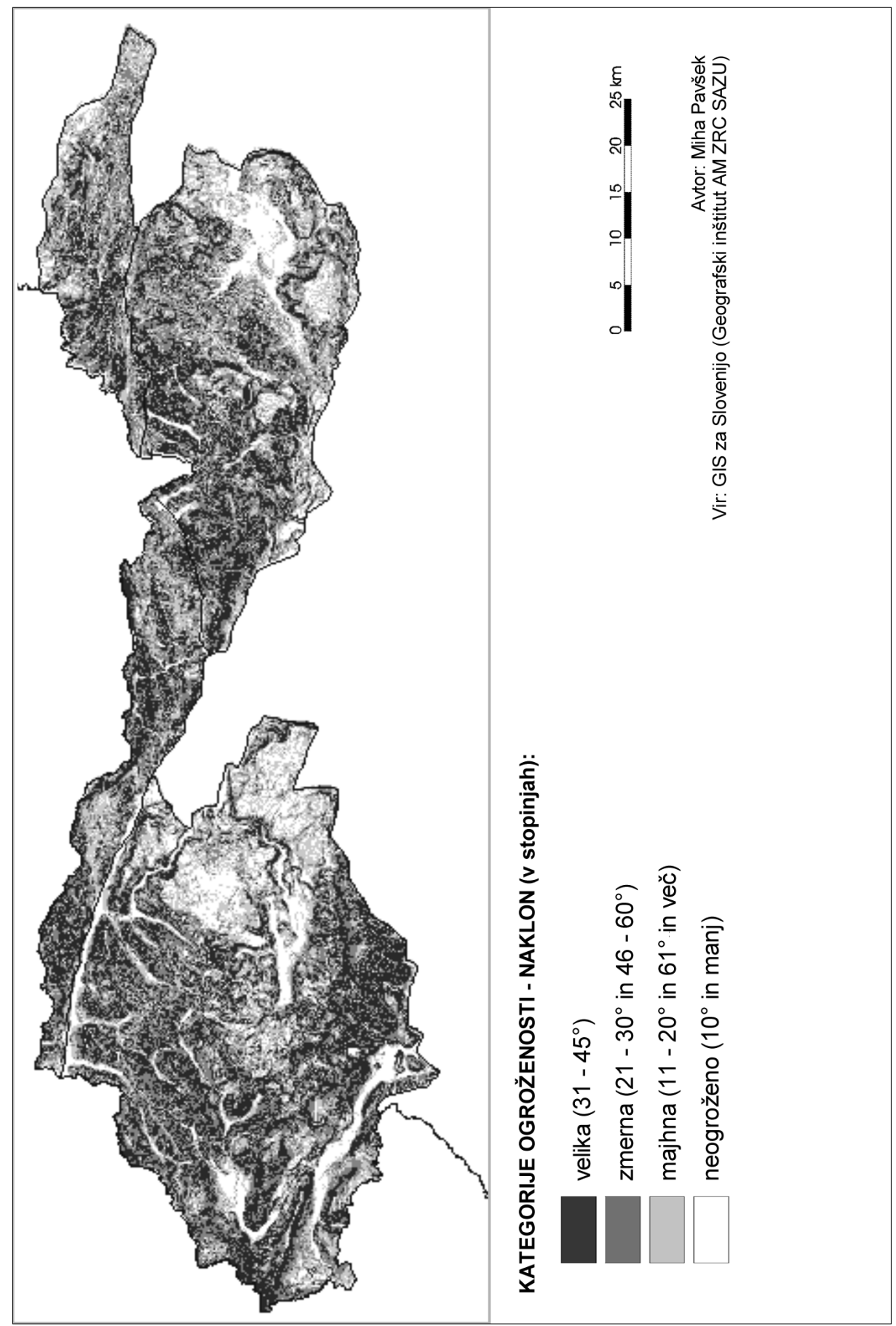

Slika 1: Simulacija lavinske ogroženosti v slovenskih Alpah - naklon. 
strmega sveta, s čimer si lahko razlagamo precejšen delež površin z veliko lavinsko ogroženostjo v Vzhodnih Karavankah. Simulacija lavinske ogroženosti glede na naklone (slika 1) nam kaže predvsem pomen gozda kot učinkovite zaščite pred snežno erozijo. Upoštevati jo moramo kot opozorilo pred neprimernimi posegi $\mathrm{v}$ gozdovih, ki so pomembni za ohranjanje naravnega ravnovesja in preprečevanje oziroma zmanjševanje snežne erozije kakor tudi erozije na splošno.

\section{RASTJE PO VIŠINI}

Naslednji pomemben dejavnik je bilo rastje, ki porašča pobočja oziroma njegova višina in gostota. Osnovni vir za določanje rastnih značilnosti slovenskih Alp glede lavinske ogroženosti je bil zemljevid realne vegetacije (Zupančič in drugi 1998, str. 118). Kljub sorazmerni prostorski nenatančnosti je po izbranih kategorijah rastja najprimernejši. Pri natančnejšem prostorskem preučevanju lavinske ogroženosti je bolje, da je zaradi nenatančnosti ne upoštevamo. Pomembna je predvsem višina rastja, ki je v veliki meri povezana tudi s starostjo združb, gostoto dreves in nekaterimi drugimi značilnostmi gozdov. Rastje mora presegati višino vsaj enega metra (Lawinenaufnahmeblatt, Hinweise für... 1980), kar ustreza povprečni višini ruševja. Pri tej višini že lahko govorimo o pomembnejšem vplivu oziroma zaščiti rastja pred snežno erozijo. Vendar velja to le do tedaj, ko ga prekrije snežna odeja. Rastje po višini sem razdelil v tri skupine (preglednica 1, stolpec 2). Pri tem so zaradi merila osnovnega vira izpadla kot neogrožena skoraj vsa manjša, nestrnjena kmetijska zemljišča.

\section{EKSPOZICIJA}

Temeljni vir za določanje značilnosti ekspozicij v slovenskih Alpah glede lavinske ogroženosti je bil zemljevid ekspozicij površja iz GIS-a za Slovenijo (GIAM). Ker so pri osnovnem zemljevidu ekspozicij upoštevane vse kotne vrednosti (od 0 do $360^{\circ}$ ), sem uporabil sloj, kjer so združene posamezne vrednosti glede na najpomembnejše strani neba $\mathrm{v}$ osem razredov $(\mathrm{S}, \mathrm{SV}, \mathrm{V}$, JV, J, JZ, Z, in SZ; Perko 1998a, str. 88), posebej pa so izločene ravnine (vse celice $\mathrm{z}$ naklonom manjšim od $\left.0,5^{\circ}\right)$.

V nasprotju z ugotovitvami o večji plazovitosti pobočij v senčnih legah (SZ-S-SV) sem se odločil za drug razmejitveni kriterij. Plazove z območja Julijskih Alp sem rastriral ter primerjal ekspozicije plazov z ekspozicijami površja. S pomočjo indeksa koncentracije $(\mathrm{IK}=$ delež plazov/delež površja x 100) 
sem nato razvrstil posamezne ekspozicije glede na simulacijo lavinske ogroženosti v ustaljene tri razrede. Tudi po podatkih iz lavinskega katastra prevladujejo na območju Julijskih Alp plaznice na južni ekspoziciji (26\%). Zato sem jo tudi pri simulaciji lavinske ogroženosti skupaj z jugovzhodno in jugozahodno ekspozicijo uvrstil v najvišji razred ogroženosti (preglednica 1, stolpec 3).

Simulacija lavinske ogroženosti glede na ekspozicijo površja nam je pokazala, da je površin z veliko stopnjo ogroženosti skoraj enkrat več kot tistih z zmerno, majhna ogroženost pa je na nekaj več kot tretjini površja slovenskih Alp. Tudi pri ekspoziciji zmanjšujejo navidez veliko lavinsko ogroženost gozdovi, ki segajo s pomikanjem od juga proti severu vse višje. Opozoriti velja še na površje v večjem delu Zahodnih Karavank in v zahodnem delu Kamniško-Savinjskih Alp, ki je predvsem po ekspoziciji pa tudi po oblikah površja in višini rastja zelo podobo grebenom na severni strani Srednje Soške doline. Razlika je le v količini padavin, kar pomeni, da lahko pričakujemo ob izdatnejših padavinah večje plazove tudi v tem delu slovenskih Alp.

\section{TRAJANJE SNEŽNE ODEJE}

Naslednji podatkovni sloj je tematski zemljevid o trajanju snežne odeje oziroma povprečnem številu dni s snežno odejo (Mlinar 2000). Domeval sem, da dlje kot traja snežna odeja, večja je tudi nevarnost proženja snežnih plazov oziroma stopnja lavinske ogroženosti površja (preglednica 1, stolpec 4). Tematski zemljevid (Mekinda Majaron 1996) so pripravili s pomočjo optimalne interpolacije oziroma tej prirejenega matematičnega modela. Poleg podatkov o trajanju snežne odeje so upoštevali še nadmorske višine, ne pa tudi ekspozicij. Zaradi majhnega števila primerljivih meteoroloških postaj to ni bilo možno, kilometrska mreže pa je povzročila, da so izpadle iz posameznih razredov višje ogroženosti tudi nekatere manjše oblike površja. Največji delež površja $(61,3 \%)$ pade v drugo stopnjo ogroženosti, več kot petina pa v prvo. Velika lavinska ogroženost je glede trajanje snežne odeje prisotna tako v nižjem visokogorju Julijskih Alp kot tudi v najvišjih delih Karavank in Kamniško-Savinjskih Alp. Opozoriti velja na nekatere proti jugu pomaknjene gorske grebene in hrbte v Julijskih Alpah (Polovnik, Črna prst, Ratitovec), kjer obleži sneg dlje časa zaradi izrazito večje količine padavin v času snežnih razmer. 


\section{MAKSIMALNA VIŠINA SNEŽNE ODEJE}

Pomemben podatek za simulacijo lavinske ogroženosti je tudi maksimalna višina snežne odeje. Kot referenčni vir sem uporabil tematski zemljevid za obdobje 1951 - 1990 (Bernot in drugi 1994), ki so ga pripravili s prostoročno interpolacijo podatkov o višini snežne odeje po posameznih meteoroloških postajah. Do ustreznega sloja sem prišel šele po vektorizaciji izvornih podatkov na topografski osnovi v merilu $1: 400.000$ ter $\mathrm{z}$ njihovo dopolnitvijo s podatki za obdobje 1977 - 1990 (Mekinda Majaron 1996, str. 56) za območje zahodnih Julijskih Alp. Prvotnih osem razredov višin snežne odeje sem prerazporedil za simulacijo lavinske ogroženosti površja $\mathrm{v}$ ustaljene tri razrede (preglednica 1, stolpec 5). Tudi tu je najbolj opazen vpliv nadmorske višine, $v$ zahodnem in južnem delu Julijskih Alp pa tudi bistveno večja letna količina padavin. Ob prehodu vremenskih front $\mathrm{z}$ zahoda, jugozahoda in juga se pridruži ciklonalnemu in v manjši meri konvekcijskemu tudi orografsko dviganje zračnih gmot, ki se na svoji poti nad Sredozemljem navzamejo vlage. Grebeni v tem delu Julijskih Alp so za omenjene zračne gmote prva višja pregrada. Učinek prisilnega dviga je najmočnejši, kadar je smer zračnih mas pravokotna s smerjo grebena oziroma gorskega hrbta.

\section{NADMORSKA VIŠINA}

Kot poseben dejavnik lavinske ogroženosti sem upošteval tudi nadmorsko višino (preglednica 1, stolpec 6). Delež snega v letni količini padavin narašča tako z večanjem geografske širine kakor tudi z naraščanjem nadmorske višine. Za Vzhodne Alpe so ugotovili, da se delež snega v celotni količini padavin na vsakih 100 metrov poveča za $3 \%$. (Kladnik 1999). Nadmorska višina je pomembna tudi pri vsakokratnem sneženju v zvezi z mejo sneženja. Na območju Alp sneži najpogosteje še približno 300 višinskih metrov pod nadmorsko višino, na kateri poteka izoterma $0^{\circ} \mathrm{C}$ (Munter 1992, str. 60). Nadmorske višine oziroma 100-metrske višinske pasove sem določil s pomočjo DMR 100 x 100 m (GIS za Slovenijo, GIAM). Mejne vrednosti razredov sem določil na osnovi več dejavnikov: meja sneženja, gozdna in drevesna meja, višinska meja stalne poselitve in drugo. Najpomembnejši pri tem so bili spet rezultati obdelave plazov iz lavinskega katastra. Pri vzorcu za Julijske Alpe sem vzel pod drobnogled vse tri povprečne nadmorske višine območja proženja: zgornjo, srednjo in spodnjo. Pri končni opredelitvi mejnih vrednosti $(1200$ in $1600 \mathrm{~m})$ sem dal poleg prej omenjenih dejavnikov največjo težo srednji nadmorski višini območja proženja. 


\section{PODNEBJE}

Kot zadnji dejavnik pri simulaciji lavinske ogroženosti sem upošteval še podnebje oziroma podnebne tipe. Podnebje združuje tudi vse prejšnje dejavnike, nekatere neposredno (snežne padavine - trajanje in višina, nadmorska višina), druge posredno (naklon, ekspozicija, rastje po višini). Zadnjega od dejavnikov za simulacijo lavinsko ogroženega površja sem uporabil predvsem za preverjanje vseh prejšnjih, še posebej za visokogorska območja. Izhodišče je bil osnutek tematskega zemljevida podnebnih tipov v Sloveniji (Ogrin 1998, str. 111), pri katerem je vzel avtor kot osnovo Köppenovo razvrstitev svetovnega podnebja. Na območju slovenskih Alp so trije najpomembnejši podnebni tipi (preglednica 1, stolpec 7).

\section{OSNOVNA SIMUALCIJA LAVINSKE OGROŽENOSTI}

Na koncu sem izdelal še simulacijo lavinsko ogroženega površja, pri kateri sem upošteval vseh sedem dejavnikov. Zadovoljive rezultate sem dobil predvsem za območja nad gozdno mejo, izpadle pa so skoraj vse krčevine pod njo. Tudi zaradi tega sem pripravil več različic. Najprej si oglejmo osnovno simulacijo lavinske ogroženosti (slika 2) in njene prostorske razsežnosti (preglednica 3). Pri tej različici sem množil med seboj vse dejavnike v preglednici 1 (stolpci 1 do 7). Pri tem so dobile celice, kjer je imel eden od dejavnikov v stolpcih 1,2 in 6 vrednost 0 tudi enako končno vrednost. To površje sem poimenoval kot neogroženo, vendar je zaradi določenih odstopanj in nenatančnosti podatkov to dejansko le pogojno neogroženo površje. Druge celice so imele vrednosti od 1 do $2187\left(3^{7}\right)$ in sem jih razvrstil v tri razrede po načelu enakomernih deležev. Na območju slovenskih Alp je nekaj več kot petina $(22,9 \%)$ ali skoraj $700 \mathrm{~km}^{2}$ površja, ki je lavinsko potencialno ogroženo.

$\mathrm{V}$ nadaljevanju sem izkoristil tematski zemljevid realne vegetacije, na katerem so poudarjeni gozdovi (Zupančič in drugi 1998, str. 118) za pregled gozdov po višinskih pasovih na tistih območjih, kjer so v vpadnici oziroma pod lavinsko ogroženim površjem. Nato pa sem dodatno izločil še vse površine pod gozdom na površju z naklonom od 0 do $20^{\circ}$, kjer je plazenje že pri majhni gostoti dreves izključeno. Ogroženost gozdov je največja tam, kjer sovpadata velika lavinska ogroženost površja (najtemneje obarvane površine) in višinski pas gozda na njegovi gozdni oziroma drevesni meji. Po tej simulaciji je na območju slovenskih Alp lavinsko zelo ogroženih okrog 10.500 ha gozda oz. $3,4 \%$ vsega gozdnatega površja. Po nekaterih grobih ocenah (Horvat 1984; Mikoš in Pintar 1983) imamo v celotni Sloveniji okrog 16.000 ha plazovitih 


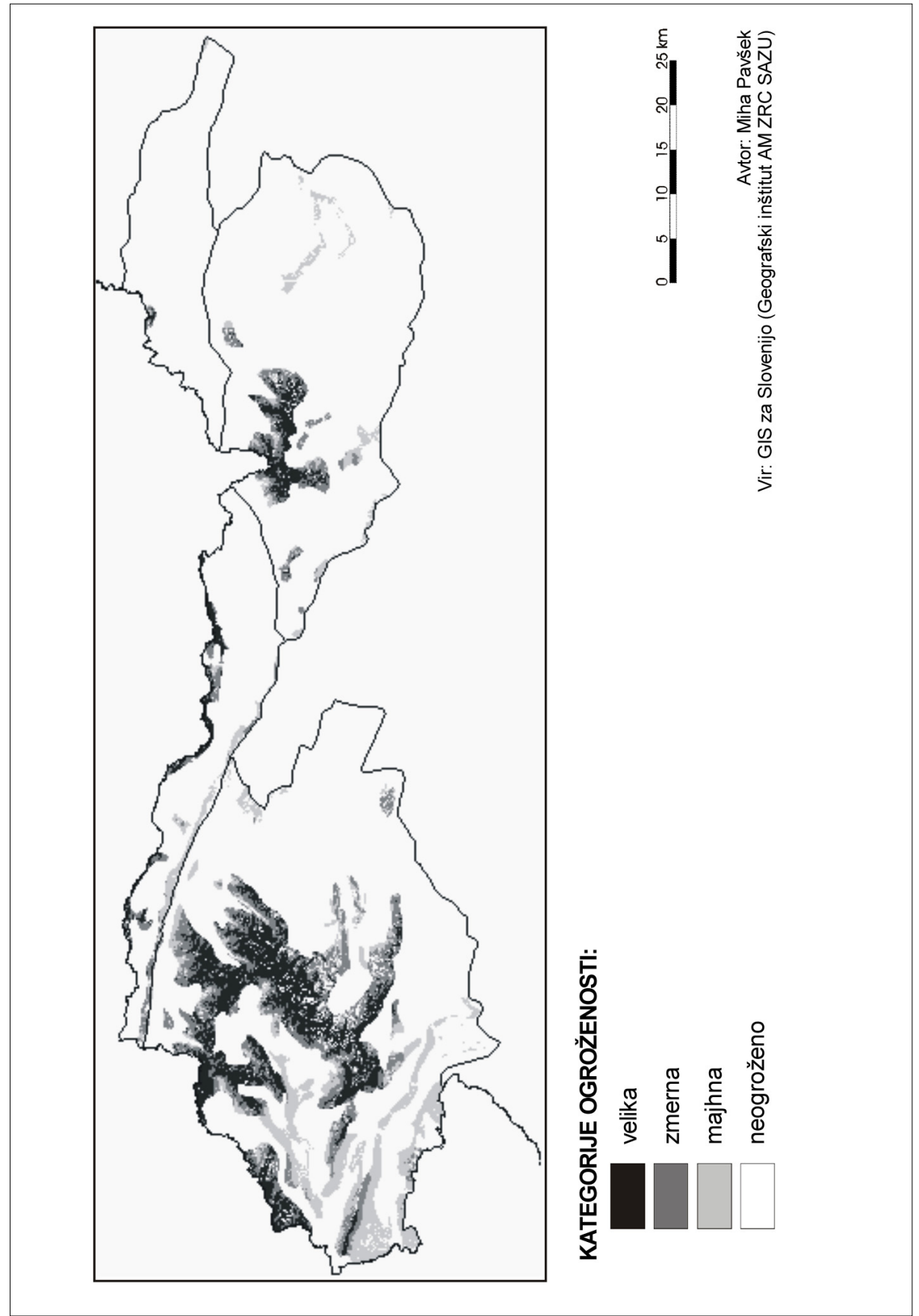

Slika 2: Osnovna simulacija lavinske ogroženosti v slovenskih Alpah. 
območij, v lavinskem katastru, kjer so zajeti le akutni plazovi, pa je skupna površina do sedaj popisanih plazov nekaj več kot 13.400 ha.

Preglednica 3: Osnovna simulacija lavinsko ogroženih površin - velikost in delež lavinsko ogroženega površja v okviru slovenskih Alp in delež v okviru vseh ogroženih površin.

\begin{tabular}{|l|c|r|r|r|}
\hline $\begin{array}{l}\text { Stopnja ogroženosti } \\
\text { (opisno) }\end{array}$ & $\begin{array}{c}\text { Stopnja ogroženosti } \\
\text { (številčno) }\end{array}$ & $\begin{array}{c}\text { Število } \\
\text { celic (ha) }\end{array}$ & $\begin{array}{c}\text { Delež od vsega } \\
\text { površja (\%) }\end{array}$ & $\begin{array}{c}\text { Delež od ogr. } \\
\text { površja (\%) }\end{array}$ \\
\hline Velika (3) & 3 & 22814 & 7,5 & 32,6 \\
\hline Zmerna (2) & 2 & 22928 & 7,5 & 32,8 \\
\hline Majhna (1) & 1 & 24211 & 7,9 & 34,6 \\
\hline Neogroženo (0) & 0 & 236195 & 77,1 & - \\
\hline skupaj: & & 306148 & 100,0 & 100,0 \\
\hline Neogroženo & 0 & 236195 & 77,1 & - \\
\hline Ogroženo & $1+2+3$ & 69953 & 22,9 & - \\
\hline skupaj: & & 306148 & 100,0 & - \\
\hline
\end{tabular}

\section{PONDERIRANA SIMUALCIJA LAVINSKE OGROŽENOSTI}

Zaradi pomembnosti naklona za plazenje snežne odeje sem se odločil še za izdelavo ponderirane simulacije lavinske ogroženosti, pri kateri sem ponderiral vrednosti za naklone, saj so ti podatki med najbolj natančnimi (slika 3). Tudi Kienholz in Grunder (1986, str. 104) sta pri delni simulaciji lavinske ogroženosti za območje proženja opredelila in ovrednotila kot najbolj plazovito površje $\mathrm{z}$ naklonom med 30 in $45^{\circ} \mathrm{C}$ (5 točk), kot zmerno ogroženo z naklonom med 45 in $60^{\circ}$ ( 3 točke) ter med 20 in $30^{\circ}$ ( 2 točki). Kot najmanj ogroženo pa površje, ki ima naklon nad $60^{\circ}$ (1 točka). Tako sem v nadaljevanju vrednosti znotraj razreda velike ogroženosti pomnožil s 3, zmerne ogroženosti z 2, razred majhne ogroženosti pa je ostal enak. Po medsebojnem množenju posameznih slojev so imele celice vrednosti od 0 do $2187\left(3^{7}\right)$, nato pa sem jih spet razvrstil po načelu enakomernih deležev $\mathrm{v}$ tri razrede.

Deleži lavinsko ogroženega površja pri ponderirani simulaciji so mnogo višji (razmerje z osnovno simulacijo je skoraj $1: 4$ ), ker nisem upošteval površja pod gozdom. Ta zemljevid nam kaže lavinsko pogojno ogroženo območje in je dobro izhodišče za nadaljnjo krajevno opredelitev dejansko ogroženega površja. Njegova uporabnost je povezana s sočasnim upoštevanjem krajevnih značilnosti rastja na ožjem območju. Predvsem je tovrstna simulacija mnogo bolj uporabna 


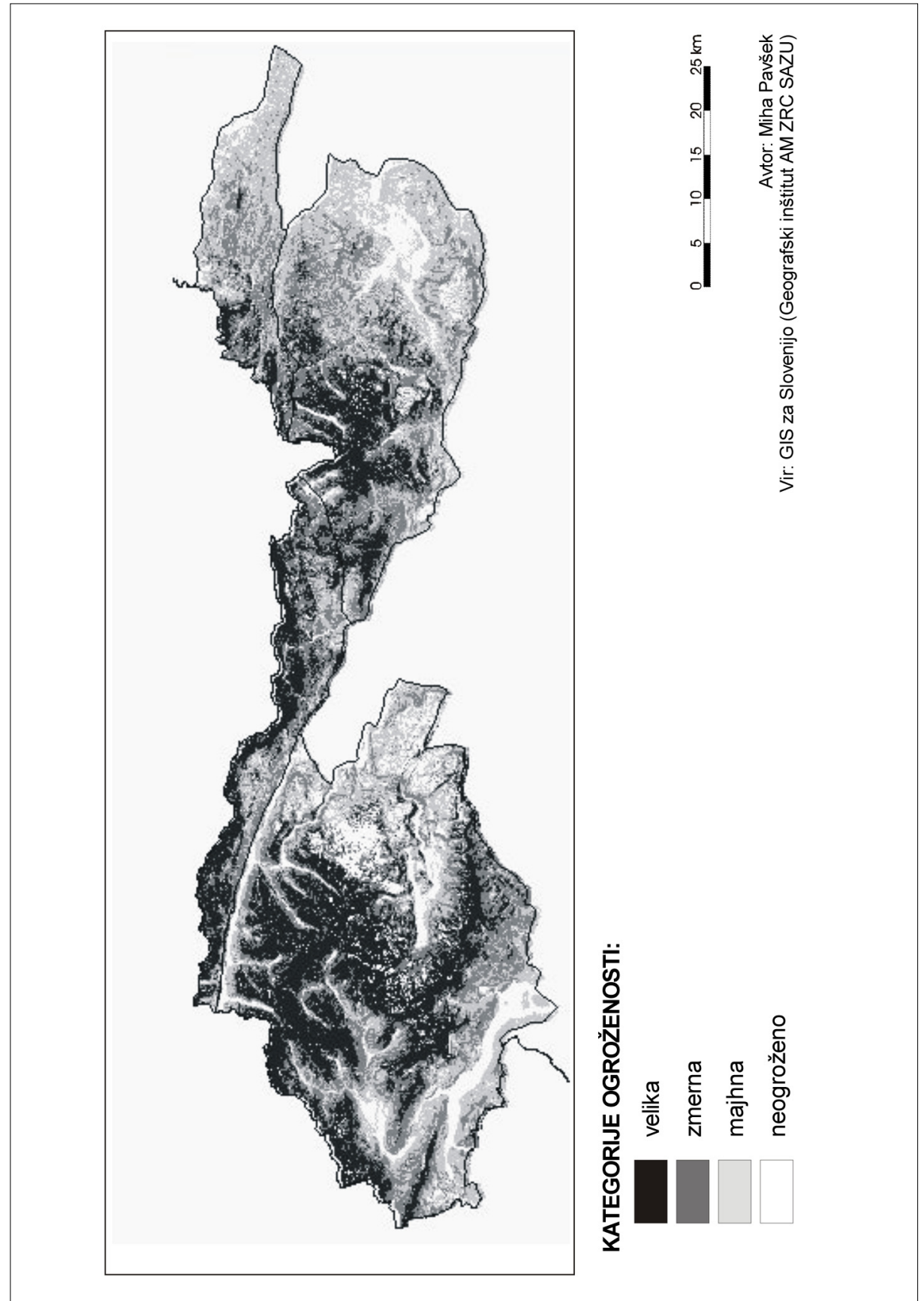

Slika 3: Ponderirana simulacija lavinske ogroženosti v slovenskih Alpah (ponderirani nakloni, neupoštevanje rastja). 


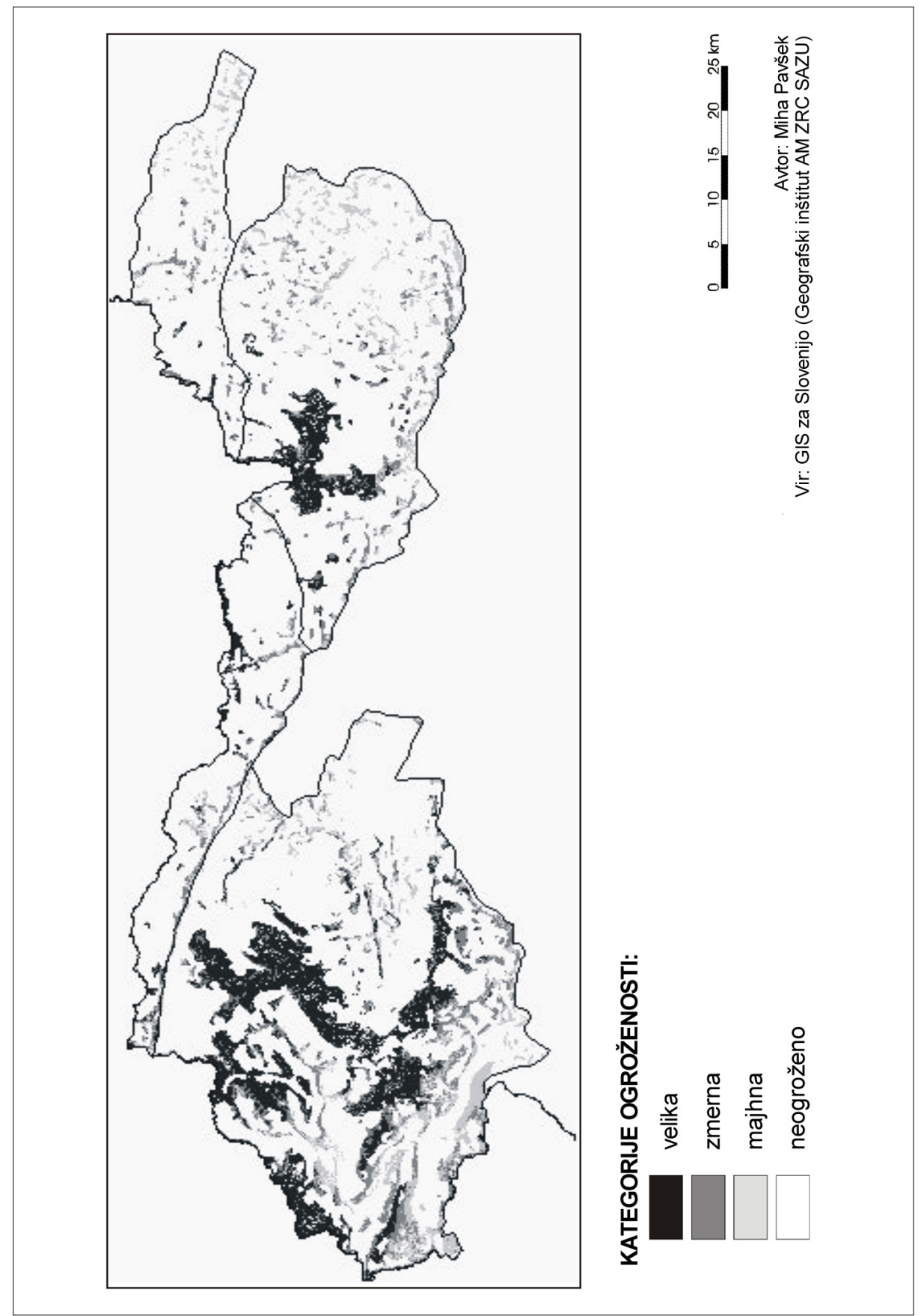

Slika 4: Dopolnjena ponderirana simulacija lavinske ogroženosti v slovenskih Alpah (ponderirani nakloni, razločevanje gozdnih in negozdnih površin). 
izven visokogorja, saj je gozd povsem izločil lavinsko ogroženost na manjših zaplatah v okviru kmetijskih zemljišč.

Dopolnjena ponderirana simualcija lavinske ogroženosti. Na koncu sem pripravil še dopolnjeno ponderirano simulacijo lavinske ogroženosti površja s pomočjo tematskega zemljevida gozdnih in negozdnih površin (vir: Biološki inštitut Jovana Hadžija ZRC SAZU). S to simulacijo sem izpostavil lavinsko ogroženost negozdnega površja na poseljenih območjih slovenskih Alp. Kot osnovo sem privzel ponderirano simulacijo lavinske ogroženosti, prek katere sem položil sloj z negozdnim površjem (slika 4).

Skupni delež lavinsko ogroženega površja pri tej simulaciji obsega več kot četrtino vsega površja slovenskih Alp in je za 2,8\% večji kot pri osnovni simulaciji. Manj je površja z majhno ogroženostjo, nekoliko več z zmerno in bistveno več z veliko ogroženostjo. Podatek o tem, da ogrožajo snežni plazovi na območju slovenskih Alp 10,5 \% površja (pri osnovni simulaciji 7,5 \%) je povsem primerljiv s podobnimi ocenami za druga gorska območja v Alpah (Kienholz in Grunder 1986, str. 107 in 108).

\section{PRIMERJAVA POTENCIALNO IN DEJANSKO LAVINSKO OGROŽENEGA POVRŠJA}

S pomočjo računalniškega programa Idrisi sem na koncu še primerjal lavinsko ogroženo površje, ki sem ga opredelil v osnovni simulaciji in tisto, do katerega sem prišel prek podatkov o plazovih, ki so v lavinskem katastru. V tem primeru gre za preverjanje površja s potencialno (simulirano) in dejansko (potrjeno) lavinsko ogroženostjo. Od celotne površine plazov iz lavinskega katastra jih je na območju slovenskih Alp več kot devet desetin. Skoraj dve tretjini površja teh plazov se prekrivata s simulacijsko opredeljenim lavinsko ogroženim površjem iz osnovne simulacije. Ostala tretjina, ki je prišla v razred neogroženo gre predvsem na račun območij gibanja in odlaganja plazov, linearne plazovitosti in plazov na gozdnatem površju. Za simulacijo lavinske ogroženosti na teh območjih bi potrebovali natančnejše izvorne podatke (DMR $50 \times 50 \mathrm{~m}$, ostali sloji na topografski podlagi v merilu $1: 25.000$ ali večjem), poleg tega pa bi morali na tem območju opraviti še podrobno geomorfološko kartiranje.

Od vse površine plazov iz lavinskega katastra je skoraj polovica na simulacijsko ogroženih območjih z veliko ogroženostjo, nekaj manj kot tretjina na tistih z zmerno in manj kot petina na simulacijsko ogroženih območjih z majhno ogroženostjo. Največja pokritost potencialne in dejanske lavinske ogroženosti je prav pri prvih dveh razredih. $\mathrm{S}$ to simulacijo sem opredelil uspešno predvsem površje z zmerno in veliko lavinsko ogroženostjo, kar je tudi najpomembnejše, saj se ujema $z$ enim od ciljev raziskave. 
Simulacijo lavinske ogroženosti sem preveril še na dva načina. Najprej sem prekril podatkovna sloja osnovne simulacije lavinske ogroženosti, pri kateri sem upošteval tudi vse gozdne površine po višinskih pasovih in plazove iz lavinskega katastra. Večina plazov iz lavinskega katastra se ujema z lavinsko ogroženimi območji, ki sem jih opredelil s simulacijo. Na nekaterih območjih lahko prepoznamo veliko ogroženost gozdov na zgornji gozdni in drevesni meji (Zadnja Trenta, Vrata, dolina Tolminke in drugod), veliko plazov pa je $\mathrm{v}$ celoti na s simulacijo opredeljenem lavinsko ogroženem območju izven gozdnih površin. S podatki o plazovih iz lavinskega katastra sem preveril tudi ponderirano simulacijo (slika 5). Kot vzorčno območje sem vzel Zgornje Posočje in Srednjo Soško dolino, saj je v lavinskem katastru največ plazov prav iz tega območja.

Slika 5: Preveritev ponderirane simulacije lavinske ogroženosti s podatki iz lavinskega katastra na izbranem območju v Zgornjem Posočju in Srednji Soški dolini.

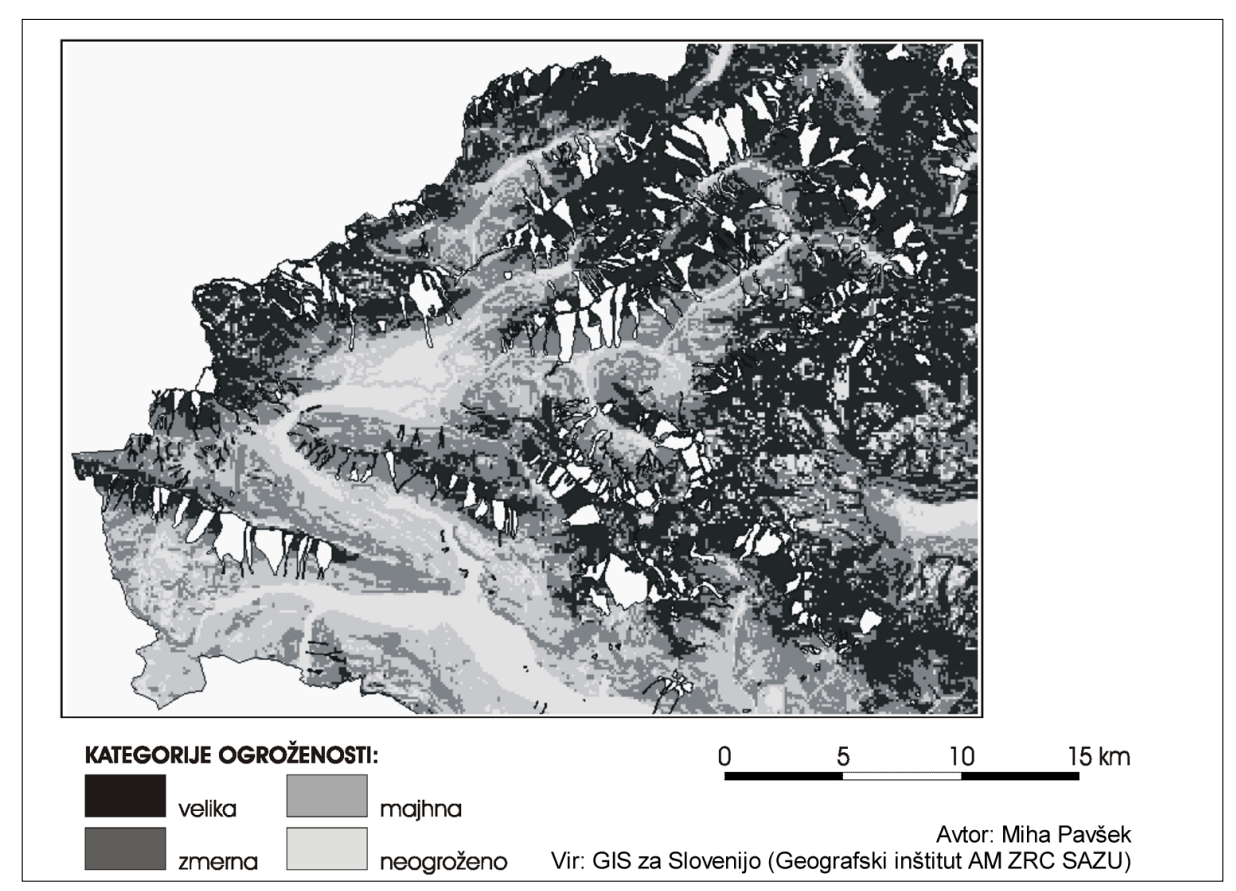

S simulacijo dobljena območja potencialne lavinske ogroženosti v veliki meri sovpadajo z dejansko lavinsko ogroženim površjem, saj se več kot devet desetin površja vseh plazov iz katastra prekriva s simulacijsko opredeljenim. 
Manj kot desetina površine plazov pa je prišla v razred neogroženo. Od vse površine plazov iz lavinskega katastra jih je več kot sedem desetin na potencialno ogroženih območjih z veliko ogroženostjo, nekaj manj kot četrtina z zmerno in le nekaj več kot $5 \%$ z majhno ogroženostjo. Pri tej simulaciji je pokritost potencialne in dejanske lavinske ogroženosti površja pri razredu $\mathrm{z}$ veliko in zmerno lavinsko ogroženostjo še za več kot desetino večja kot pri preverjanju osnovne simulacije. Seveda ne smemo pozabiti, da je na ta način dobljena velikost lavinsko ogroženega površja zaradi neupoštevanja gozdov precenjena. Primerjava med potencialno in dejansko ogroženim območjem kaže, da je ogroženost pri simulaciji bolj divja, površinsko neenakomernejša. Zavedam se, da sem uporabil sorazmerno velike poenostavitve, ki pa jih lahko glede na zahteve in potrebe tudi nekoliko prilagodimo.

\section{SKLEP}

Za natančnejši model simulacije lavinsko ogroženega površja sta najpomembnejša natančnost izvornih podatkov in izhodiščna hipoteza. Z modelom dobljeno lavinsko ogroženo površje je dobro izhodišče za natančnejše krajevno preučevanje lavinske ogroženosti površja kot tudi za vsakokratno oceno in napoved lavinskih razmer v zimski sezoni. S tovrstnimi simulacijami bi bilo moč v prihodnje predstaviti tudi ogroženost površja glede na različne scenarije pokrajinskega razvoja: površje brez gozda, varstveno stanje, prvotno stanje in stanje ob nadaljevanju intenzivnega razvoja turizma. Primerjava potencialne in dejanske lavinske ogroženosti nam omogoča premišljeno in neposredno razvrščanje območij po stopnjah lavinske ogroženosti. Ponderirana simulacija, ki nam predstavlja pogojno lavinsko ogroženo površje nam kaže hkrati tudi latentno ali prikrito lavinsko ogroženost površja. Na to pozabljamo pri večini pojavov povezanih s snežno erozijo. Njihova povratna doba najpogosteje presega človekovo opažanje pokrajinskih sprememb, zato se izkušnje in spoznanja praviloma ne prenašajo med generacijami. To lahko povzročijo le izjemni dogodki, na katere pa moramo biti vedno ustrezno in pravočasno pripravljeni ter glede na možnosti tudi opozorjeni.

\section{Literatura:}

Bernot, F. in drugi, 1994, Ogroženost Slovenije s snežnimi plazovi (študija). Podjetje za urejanje hudournikov. 48 str. Ljubljana.

GIAM - Geografski inštitut Antona Melika ZRC SAZU, Geografski informacijski sistem (GIS) za Slovenijo.. Ljubljana. 
Horvat, A., 1984, Izbrana poglavja s področja snežne erozije (skripta). 38 str. + priloge. Ljubljana.

Kienholz, H., Grunder, M., 1986, Naturgefahren: Entwicklung eines Modells durch visuelen Kartenvergeleich. Erfahrungen aus dem MAB-Testgebiet Davos. V: Jahrbuch der Geographischen Gesellschaft von Bern. Letnik 55/1983-1985, str. 95-110. Bern.

Kladnik, D., 1999, Sneg. Geografija na teletekstu TV Slovenija (http://www. zrc-sazu.si/giam/ZGDS-11-12-1999.htm\#Sneg). Ljubljana.

Lawinenaufnahmeblatt - Hinweise für Planungen der Raumplanung, des Bauwesens und des Sicherheitswesens. V: Richtlinien des Bundesministeriums für Land- und Forstwirtschaft über Hinderungsgründe (Zl. 52. 240/03-VB 7/80). 1980.

Mekinda Majaron, T., 1996, Average yearly number of days with snow cover (period od reference 1961-1990), Maximum snow cover depth with return period 50 years (period of reference 1977-1990). V: Climate of Slovenia. str. 55 56. Hidrometeorološki zavod Republike Slovenije. Ljubljana.

Mikoš, M., Pintar, J., 1983, Snežni plazovi, njihovo ugotavljanje in vrednotenje (skripta). Vodnogospodarski inštitut. 69 str. + priloge. Ljubljana.

Munter, W., 1992, Neue Lawinenkunde. Ein Leitfaden für die Praxis. 200 str. Bern.

Ogrin, D., 1998, Podnebje. V: Geografski atlas Slovenije, str. 110-111. Ljubljana.

Perko, D., 1998a, Ekspozicije površja. V: Geografski atlas Slovenije, str. 88-89. Ljubljana.

Perko, D., 1998b, Pokrajine. V: Geografski atlas Slovenije, str. 120-125. Ljubljana.

Zupančič, M., Seliškar, A. in Žagar, V., 1998, Rastlinstvo. Geografski atlas Slovenije, str. 116-119. Ljubljana.

\title{
SIMULATION OF AVALANCHE THREAT IN THE SLOVENE ALPS
}

\begin{abstract}
Summary
According to its relief, Slovenia is highly variegated and its landscape diverse, and for this reason it is threatened by numerous natural accidents, among which are avalanches. The data on avalanches in the avalanche cadastre shows us the actual avalanche threat. On the basis of previous findings and with the help of data from Slovenia's Geographical Information System, we undertook to determine potential avalanche surfaces in the Slovene Alps. In so doing, we
\end{abstract}


considered the results of data processing on avalanches in the Julian Alps $(\mathrm{N}=506)$ from the avalanche cadastre and data layers on natural and geographical elements in high-mountain regions.

During the simulation we considered the seven most important factors: slope, vegetation according to altitude, exposition, the duration and maximum thickness of the snow cover, altitude, and climate. We ranked each factor according to the level of threat into three or four classes (high, moderate, and low threat, unthreatened). The border values were determined with the help of data from scientific sources and literature, the avalanche cadastre, and the Geographical Information System. Finally, the total avalanche threat to individual hectare cells was determined. The areas thus acquired are those we mark as avalanche trigger areas. During the basic simulation we did not weight individual factors, while during the weighted simulation we weighted slope since it is the most significant factor. Vegetation studies enabled us to prepare a supplementary weighted simulation.

The results of the simulations of avalanche threat are presented on synthetic thematic maps. On checking the data on avalanches in the avalanche cadastre, we found we had acquired satisfactory results mainly for areas above the tree line. A comparison between actual and potential avalanche threat areas reveals that the simulated threat is less accurate, unconnected, and superficially disproportionate. For a more accurate model of any avalanche threat simulation, the accuracy of the original data and a suitable initial hypothesis are the most important factors. These must be particularly considered in future in preparing similar thematic maps for smaller, geographically bounded areas as the obligatory professional basis for spatial planning in Slovenia's alpine regions. 